\title{
THE LIFE AND WORK OF ROBERT J. ADCOCK. PART II. BIOGRAPHY AND ESTABLISHMENT OF AUTHORSHIP
}

\author{
by \\ Richard J. Howarth ${ }^{1 *}$ and Wolfgang H. Müller ${ }^{2}$
}

${ }^{1}$ UCL Earth Sciences, 5 Gower Place, London WC1E 6BS, UK.

${ }^{2}$ Technische Universität Berlin, Fak. V, Institut für Mechanik, Lehrstuhl für Kontinuumsmechanik und Materialtheorie, Sekr. MS 2, Einsteinufer 5, D-10587 Berlin, Germany.

Between 1870 and 1896, the American mathematician Robert Jackson Adcock (1826-1895) contributed a number of short articles to early mathematical journals such as The Analyst. His biography is given here for the first time: An obscure figure hitherto associated with the history of regression analysis and least-squares he has, on occasion, been confused with a nephew of the same name. Before the American Civil War, Adcock was first a pupil, then taught, at the Western Military Institute, which became the Kentucky Military Institute, near Frankfort, Kentucky. Afterwards, despite occasionally being hospitalized during periods of mental illness, he became a wealthy farmer who could afford mathematical recreation as a hobby. His self-published pamphlet Gravitation to the sphere and the two ellipsoids of revolution (1872), recently discovered in the Library of the Royal Society, is discussed in Part I. We establish his authorship of all mathematical works by 'R.J. Adcock'.

\section{Keywords: biography; history of mathematics; Knox College; Kentucky Military Institute}

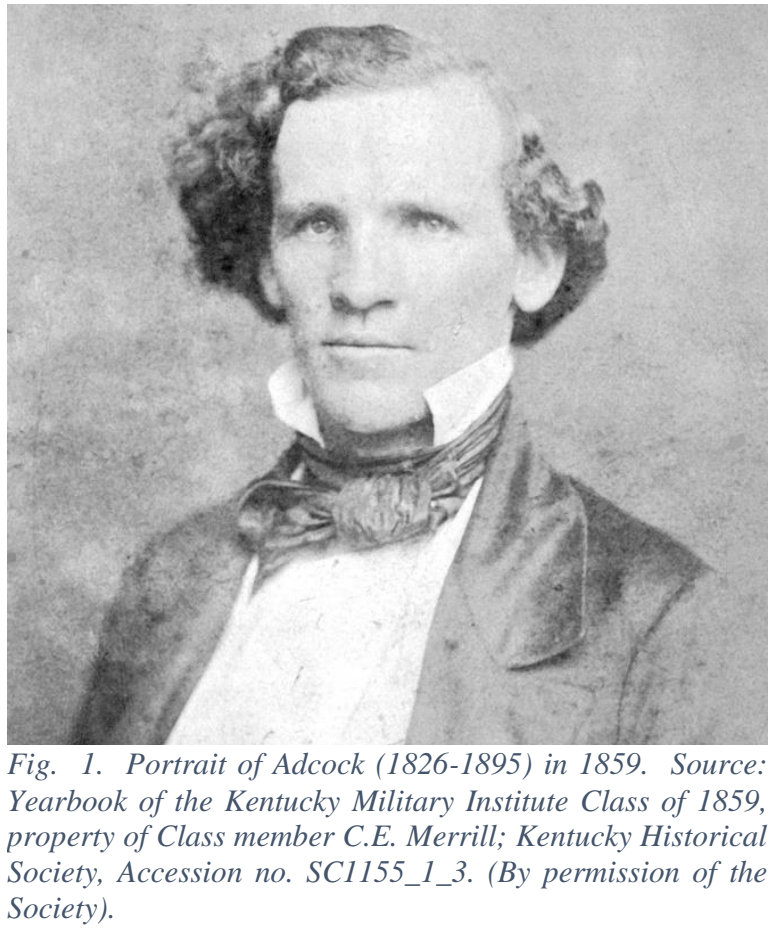

\section{INTRODUCTION}

For many years, the name of the American mathematician, 'R. J. Adcock,' (Fig. 1) has been associated with the history of least squares and regression, specifically, fitting a straightline relationship, $y=\alpha+\beta x$, when both $x$ and $y$ are subject to error. ${ }^{1}$

However, the majority of his mathematical publications were short articles; the setting of mathematical conundrums; or providing solutions either to his own problems, or to those set by others. These appeared mainly in the journal The Analyst (1874-1883), which was aimed at those 'in pure and applied Mathematics, embracing especially all new and interesting discoveries in theoretical and

*r.howarth@ucl.ac.uk; whmueller1000@gmail.com.

Robert J. Adcock, 'The correct method of least squares'. The Analyst, 1, 64 (1874a); 'Note on the method of least squares'. The Analyst, 4, 183-184 (1877); 'Least squares'. The Analyst, 5, 21-22 (1878a); 'A problem in least squares'. The Analyst, 5, 53-54 (1878b); 'Extension of the method of least squares to any number of variables'. The Analyst, 7, 22-23 (1880); Stephen M. Stigler, 'Mathematical 
practical astronomy, mechanical philosophy, and engineering'. ${ }^{2}$ He also published notes in The Annals of Mathematics (which took over from The Analyst in March 1884); The American Mathematical Monthly (which commenced in 1894); and single contributions to The Astronomical Journal and The Sidereal Messenger (Fig.2). Unfortunately, his articles were sometimes marred by algebraic or arithmetic errors, both of his own making ${ }^{3}$ or attributed to the typesetter. ${ }^{4}$ As regards the former, Finney ${ }^{5}$ remarked:

\begin{abstract}
Adcock $^{6}$ ended by publishing an expression for estimating [the coefficient $\beta$ in $y=\alpha+\beta x$ ] that was so dimensionally absurd as to occasion surprise that no referee noticed the error. ${ }^{7}$. . After making a gross arithmetical error in substitution [of numerical values] into his own incorrect formula, he concluded with a numerical result that agreed neither with his own formula nor with today's well-known correct formula! Kummell presented the correct result. ${ }^{8}$
\end{abstract}

This may have been the reason why Adcock lamented that his 'correct demonstration of the principle of Least Squares' had not made 'a single disciple.' This was not the only occasion which suggests that he did not check his work carefully enough before submitting it for publication. His self-published pamphlet Gravitation to the sphere and the two ellipsoids of revolution: ratio of the axes of a rotating fluid mass (transcribed in Part I of this paper), ${ }^{10}$ concluded with an entire page of 39 'errata.' It addressed the problem of the shape or 'figure' of the Earth. In it, Adcock gave a complete, if somewhat crude, derivation of the solution of a problem attempted by Isaac Newton (1642-1726/7), Pierre-Simon Laplace (1749-1827), Carl Friedrich Gauss (1777-1855) and Johann Peter Gustav Lejeune Dirichlet (1805-1859): namely, determining the flattening achieved by a rotating self-gravitating homogeneous ellipsoidal fluid mass. The tools of potential theory and vector algebra were yet to come, nevertheless, he derived an explicit solution for the potential of a homogeneous ellipsoid which, until now, was

statistics in the early States'. Annals of Statistics, 6, 239-265 (1978); David John Finney, 'A note on the history of regression'. Journal of Applied Statistics, 23 (5), 555-557 (1996); Richard William Farebrother, Fitting linear relationships. A History of the Calculus of Observations 1750-1900. (Springer-Verlag, New York, 1999).

Joel E. Hendricks, 'Introductory remarks'. The Analyst, 1, 1-2 (1874).

Adcock (1878b), op. cit. (note 1), at p. 54, eq. 5.

Robert J. Adcock, 'Solution [to problem 239]'. The Analyst, 6, 49 (1879).

Finney, op. cit. (note 1), at p. 557.

Adcock (1878b), op. cit. (note 1).

In the mid- $19^{\text {th }}$ Century many 'editors of scientific journals made publishing decisions by personal fiat' and the modern system of peer review was still unusual in the 1930s (Alex Csiszar, 'Peer review:

Troubled from the start'. Nature, 532, 306-308 (2016) at p. 306). However, in 1752 the Royal Society in London established a Committee of Papers to judge which papers to accept for their Philosophical Transactions and used standardized referee report forms from the 1890s (Aileen Fyfe, Noah Moxham, Julie McDougall-Waters and Camilla Mork Røstvik. 2018. The secret history of the scientific journal. The economic, social and cultural history of the world's oldest scientific journal, 1665-2015. (2018) (https://arts.st-andrews.ac.uk/philosophical transactions/project/)).

$8 \quad$ Charles Hugo Kummell, 'Reduction of observation equations which contain more than one observed quantity'. The Analyst, 6, 98-105 (1879).

9 Robert J. Adcock, 'Solution of problem 206'. The Analyst, 5, 149-150 (1878c) at p. 149.

10 Robert J. Adcock, Gravitation to the sphere and the two ellipsoids of revolution: ratio of the axes of a rotating fluid mass. (Wilstach and Baldwin, Cincinnati, Ohio, 1872), 8 pp. 


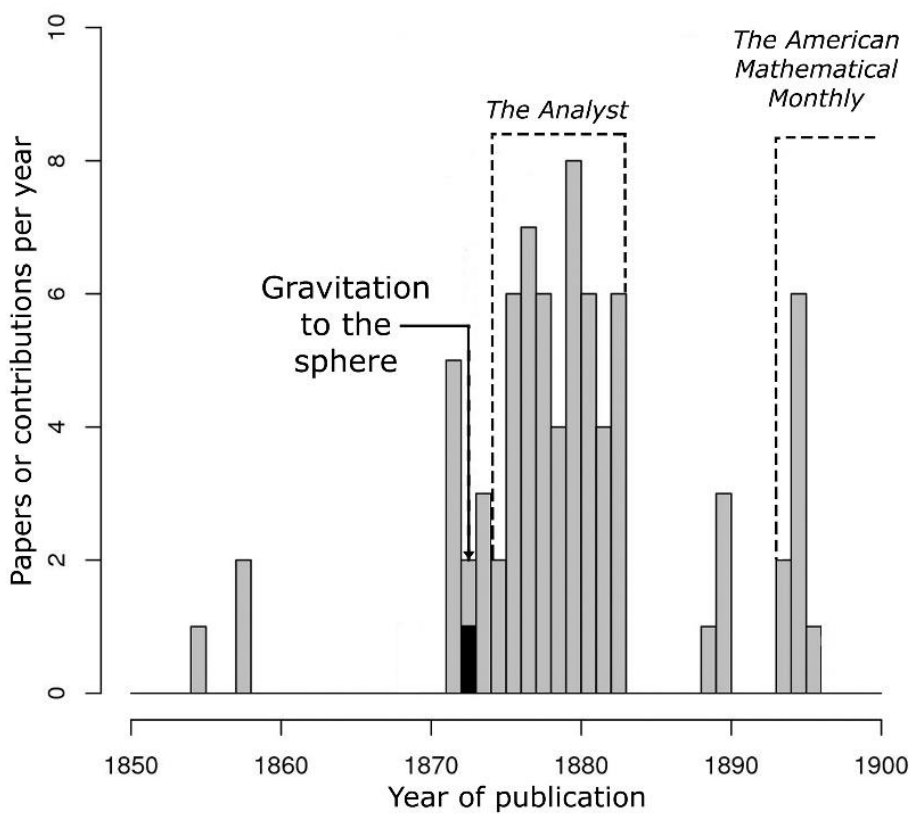

Fig. 2. Number of 'R.J. Adcock's' mathematical contributions per year and the principal journals in which they were published; Gravitation to the sphere was self-published. believed to have first been obtained in $1935,{ }^{11}$ and correctly calculated the flattening of such a model. It was a remarkable feat.

Hitherto, relatively little has been known of Adcock's background, so much so that, in the literature, he has frequently been confused with a younger relative of the same name, ${ }^{12}$ a misattribution which has recently been acknowledged by Stigler. ${ }^{13}$ A comprehensive account of Adcock's life, so far as its details can now be ascertained, is given here for the first time.

\section{'R.J. ADCOCK' TO 1859}

Information regarding the mathematician who was usually known as 'R.J. Adcock' is relatively clear until the summer of 1859: Robert Jackson Adcock (1826-1895) and his twin brother, Joseph Washington Adcock (1826-1901), were born on January 22, 1826 to Cynthia R. Adcock (née Christian, 1805-1865), wife of Edmund Adcock (1800-1859), in Kanawha City, near Charlestown, Kanawha County, Virginia (a part of the state which became West Virginia following secession in 1863). Their sister, Cynthia Elizabeth Adcock (1823-1845) was born three years earlier. ${ }^{14}$

In 1828, the family moved to Crawford County, Indiana, then to Knox County, Illinois (IL) (Fig. 3) in 1830, before eventually joining a small farming settlement, which became known as Kelly Township in 1853. Life was still sufficiently that of the frontier such that his grandfather, Edmund Adcock, had fought as a Private in the Odd Battalion, Mounted Rangers

11 Otto Heymann, 'Über das Gravitationspotential eines homogenen Ellipsoids'. Astronomische Nachrichten, 256, 181-186 (1935).

12 e.g. by Stigler, Finney and Farebrother, op. cit. (note 1) and by Rod E. Deakin and Max N. Hunter, 'Fitting a line of best fit to correlated data of varying precision'.

(http://www.mygeodesy.id.au/documents/ Fitting a straight line.pdf, 2017) and Dietrich Stoyan and Thomas Morel. 'Julius Weisbach's pioneering contribution to orthogonal linear regression (1840)'. Historia Mathematica, 45, 75-84 (2018).

13 Stephen M. Stigler, Early and often: Some history of statistics in Chicago universities. [pers. comm.; printed version of talk given at the Joint Statistical Meetings, Chicago, 31 July, 2016]. 7 pp.

14 In the case of all 'Adcock's and related persons mentioned in this article, where relevant, U.S. Internal Revenue Service Tax Assessment Lists, Federal Census (including Non-Population Schedules), Voter Registrations, U.S. Civil War Draft Registrations and other details of soldiers who fought in the U.S. Civil War, Indexed County Land Ownership, School Catalogs and Find a Grave Index entries were checked using the on-line databases of the internet genealogy company Ancestry.com, Lehi, UT (which now include Fold3.com databases). 
of the Illinois Volunteers in the so-called 'Black Hawk War,' 8-27 August 1832, against local Indians. There were no schools when they arrived and the children were home-educated, but from 1837 they attended a local school which had been established about three miles $(5 \mathrm{~km})$ away from their home. ${ }^{15}$ The brothers residence is given as Henderson Grove in 1848, so the school was almost certainly the one opened by Nehemiah Losey (1804-1875) in the autumn of 1836 'at "Log City," Henderson Grove', ${ }^{16}$ just across the county line in Knox County from where the Adcock family had settled, and some $3.5 \mathrm{mi} \mathrm{NW}$ of the centre of what is now Galesburg. ${ }^{17}$

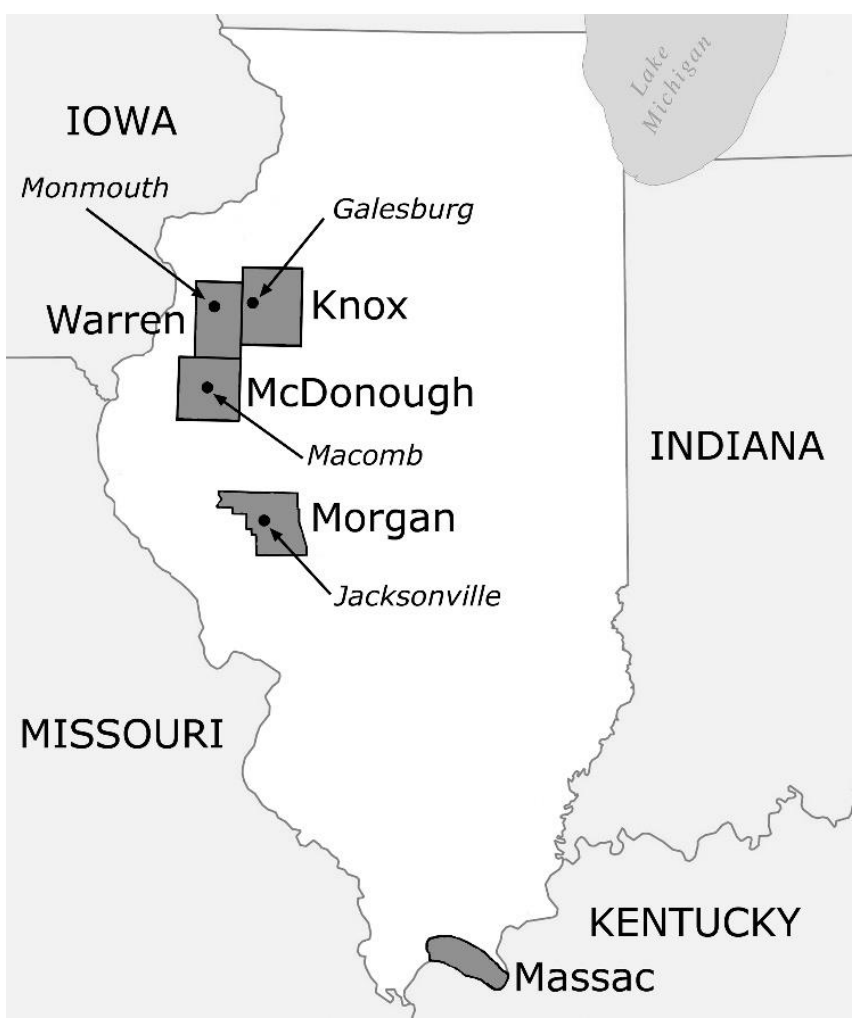

Fig. 3. Counties and major towns in Illinois mentioned in the text. Redrawn from http://www.mapofus.org/wp-content/uploads/2013/ 09/IA-county1.jpg.

However, from 1841, the Knox curriculum consisted of: Latin, Greek, religious studies, natural philosophy, mathematics, astronomy, chemistry, mineralogy (they had a cabinet containing

15 Anonymous (ed.), The past and present of Warren County, Illinois. (H.F. Kett, Chicago, 1877); Hugh R. Moffet and Thomas H. Rogers (eds.), 'History of Warren County', in: Newton Bateman and Paul Selby (eds), Historical encyclopedia of Illinois, vol. 2. (Munsell Publishing Co., Chicago, 1903). pp. 685-1040. Newton Bateman, Paul Selby, W. Selden Gale and George Candee Gale (eds.), Historical Encyclopedia of Illinois and Knox County. (Munsell, Chicago, 1889).

17 Martha Farnham Webster, Seventy-five Significant Years. The Story of Knox College 1837-1912. (Wagoner Printing Co., Galesburg, IL., 1912).

18 George Washington Gale, Brief History of Knox College, situated in Galesburgh, Knox County, Illinois; with sketches of the first settlement of the town, with a discourse on "Public men, and public institutions of the church" by J. Blanchard. (C. Clark, Cincinnati, 1845). Grant Forssberg, Knox College Timeline 1826-1899. (2010) (https:www.knox.edu/about-knox/ourhistory/perspectives-on-knox-history/timeline).

20 Anonymous, Catalogue of the Corporation, Officers and Students, of Knox College, for the year ending June $26^{\text {th }} 1850$. (Southwick Davis, Galesburg, 1850) at p. 20. 
over 500 specimens) and physiology; ${ }^{21}$ students were taught both mathematics and natural sciences by Losey. ${ }^{22}$ The course of study in mathematics, which Adcock must have followed, consisted of:

Year 1, Freshman Class: Term 1: Bourdon's Algebra; Term 2: Playfair's Euclid.

Year 2, Sophomore Class: Term 1: Applications of algebra to geometry; Playfair's Plane and

Spherical Trigonometry; Day's Mathematics, Logarithms and Plane Trigonometry. Term 2: Day's

Mathematics continued - Mensuration of Superscies and Solids, Isoperimetry, Mensuration of Heights and Distances, Navigation and Surveying; Bridge's Conic Sections.

Year 3, Junior Class: Term 1: Whateley's Logic; Term 2: Astronomy, with Calculation of Eclipses.

Year 4, Senior Class: No mathematics or science taught. ${ }^{23}$

In the period leading up to the Civil War, literary societies formed an important aspect of college life and Adcock was one of a group of fourteen students who founded the 'Gnothautii Literary Society' in November 1849, the name having been suggested by their Greek master, based on the phrase ' $\gamma \nu \omega$ ' $\theta l \sigma \alpha v \tau o$ v' (gnōthi sauton; know thyself). It had 'for its object the development of intellectual and moral strength and the cultivation of executive and administrative talent,' with essays being read, or debates being held, at its weekly meetings. Adcock was elected Vice-President and stayed on at the College until the Summer of $1850 .^{24}$ He then left to study at the Western Military Institute, Kentucky (KY). Presumably, he had by that time already shown a strong aptitude for mathematics and it was thought that a change of educational establishment would enable him to take advantage of a more mathematical and science-based curriculum.

His brother Joseph had left the College in the previous summer, without graduating, but nevertheless went on to become a successful and wealthy farmer 'known as a man of fine education and mental equipments, ${ }^{, 25}$ who eventually owned more than 1000 acres of land. He served as Supervisor of Kelly township in 1871-3 and as Warren County Surveyor at an unrecorded earlier time. ${ }^{26}$ As will be seen, the fact that he was solidly established would in due course prove a fortunate circumstance for his twin.

$21 \quad$ Forssberg, op. cit. (note 19)

22 Bateman et al., op. cit, (note 16).

23 Anonymous, op. cit., (note 20), at pp. 20-21. The textbooks referred to were almost certainly: Charles Davies, Elements of Algebra: Translated from the French of M. Bourdon. Revised and adapted to the course of mathematical instruction in the United States. Revised edn. (A.S. Barnes, Philadelphia, 1842); John Playfair, Elements of Geometry: Containing the First Six Books of Euclid, with a Supplement on the Quadrature of the Circle, and the Geometry of Solids; to which are added, Elements of Plane and Spherical Trigonometry. (W.E. Dean, New York, 1846); Jeremiah Day, A treatise of plane trigonometry, and the mensuration of heights and distances: to which is prefixed a summary view of the nature and use of logarithms: adapted to the method of instruction in schools and academies; A practical application of the principles of geometry to the mensuration of superficies and solids: adapted to the method of instruction in schools and academies. (Mark H. Newman, New York, 1848); Bewick Bridge and Frederick Augustus Porter Barnard, A treatise on the construction, properties, and analogies of the three conic sections. (Hezekiah Howe \& Co., New Haven, 1836); Richard Whately, Elements of logic: comprising the substance of the article in the Encyclopedia Metropolitana: with additions, \&c. (William Jackson, New York, 1834). Charles J. Sellon, A Review of the Commerce, Manufactures, and the Public and Private Improvements of Galesburg; containing A Brief History of Knox College, and Sketches of the First Settlement of the Town. (J.H. Sherman, Galesburg, 1857) at p. 31.

25 Moffet and Rogers, op.cit. (note 15) at p. 925.

26 Anonymous, op. cit. (note 15); Anonymous (ed.), Portrait and Biographical Album of Warren County, Illinois. (Chapman Bros., Chicago, 1886). 
The Kentucky Military Institute at Franklin Springs, about 6 miles $(10 \mathrm{~km})$ south of Frankfort, KY, was founded in 1846 by Col. Robert Thomas Pritchard Allen (1813-1888), a graduate of the United States Military Academy at West Point, New York, and was intended to be the first of its kind in the West. In 1847, it changed its name to the Western Military Institute (WMI) and was re-established at Georgetown, Scott County, KY, some 18 miles (30 km) east of Frankfort, in February of that year. Both institutions were modelled after the U.S. Military Academy on the basis that:

\begin{abstract}
A system comprehending military instruction ... as an accessory to education, is found to promote personal and purely peaceful objects by no means unimportant; such as the establishment of a firm, graceful and manly carriage, by daily drill; of personal neatness, economy, equality and a just appreciation of others upon merit only, by uniform dress; of a more perfect physical development and proportionate mental vigour, by healthful exercise; of good habits, method, promptness and subordination, and hence increased application to study, by military organization. All these are designed to be gained by superadding to the Course, military instruction at hours usually lost or misspent, on the voluntary system. There are daily military exercises on the field ... throughout the entire course; but without prejudice to studies. ${ }^{27}$
\end{abstract}

Reveille (roll-call) was at daybreak and Taps (lights out) at 10 p.m., in between-times, the students were kept continually busy, either with study or military exercises of some kind. The annual fee was $\$ 160[\$ 5,310 \text { today }]^{28}$

The WMI's first Superintendent was a West Point graduate, the mathematician and civil engineer, Col. Thornton Fitzhugh Johnson (1805-1851) and, at the time Adcock was a student, several members of the staff, such as: Edwin Wright Morgan (1814-1869), Superintendent (1849-51); Bushrod Rust Johnson (1817-1880), Professor of Natural Philosophy and Mathematics (1849-51), and William Read, Professor of Natural and Experimental Philosophy (1851-53) had also been educated at West Point. ${ }^{29}$

On 7 January 1850, the WMI moved to Blue Lick Springs in Nicholas County, KY, and the Federal Census of 25th September 1850 lists the 23 year old Robert Adcock as one of its student body. Blue Lick Springs is today $448 \mathrm{mi}(720 \mathrm{~km})$ by road from Galesburg. Travelling mainly via the Mississippi and Ohio Rivers would mean a journey of about $760 \mathrm{mi}(1223 \mathrm{~km})$. At that time, there were no long-distance railroads in Illinois, so how would he have got there? In 1849 steamboats averaged a speed of $9 \mathrm{mph}$, compared with $5 \mathrm{mph}$ travelling by stagecoach, so the overall journey-time by river would be about 3.5 days, compared with 7.5 days by road (stagecoaches had to exchange horse teams every 10-15 miles and rarely exceeded 60 miles per day). ${ }^{30}$

27 Anonymous, Catalogue of the Officers and Cadets of the Western Military Institute for the Collegiate Year 1850-51. (Publisher not stated, Drennon Springs, 1851), at. pp. 15-16.

28 Converted using Consumer Price Index via: https://www.measuringworth.com/calculators/uscompare/.

29 George W. Cullum, Biographical Register of the Officers and Graduates of the U.S. Military Academy at West Point, N.Y. from its Establishment, March 16, 1802 to the Army Re-organization of 1866-67. 2 vols. (D. Van Nostrand, New York, 1868).

30 Anonymous. Steamboat Travel on the Mississippi (New-Orleans Picayune, Sept. 18, 1864, p.6) in: The New York Times archives. (https://www.nytimes.com/1864/09/18/archives/ steamboat-travel-on-themississippi.html); Gary Gorton, 'Ante Bellum Transporation Indices'. 43 pp. (http://faculty.som.yale.edu/garygorton/documents/AnteBellumTransportationIndices.pdf, 1989). 
Following Thornton Johnson's death, in February 1851 the WMI relocated to Drennon Springs in Henry County, KY, and Bushrod Johnson took over as Superintendent. However, in March of that year, Allen reappeared, establishing the Kentucky Military Institute (KMI) close to its original location, near Frankfort, with himself as Superintendent. For a while, Johnson and some other former members of staff carried on the WMI at Drennon Springs, but in February 1854 it moved to Nashville, Tennessee, as a 'Collegiate Department' of the University of Nashville. ${ }^{31}$

So Adcock completed his Third and Fourth Year education at the WMI/KMI, the mathematics component being based around differential and integral calculus, as taught from a textbook written by another West Point graduate, Albert E. Church (1807-1878). ${ }^{32}$ Adcock would also learn about optics, electricity, magnetism and astronomy, as well as aspects of civil engineering and architecture, mineralogy and mining, languages and ethics. In his final year, Johnson became Superintendent, and mathematics was taught by James F. Hamilton ( $b$. 1828).

Adcock was one of four students awarded his Bachelor of Arts degree at the Commencement Ceremony of 16 July 1851. Presumably as a result of his aptitude for mathematics, it seems he had already been appointed to the staff, since 'Capt. R.J. Adcock, A.B., Assistant Professor of Mathematics,' appears among the staff listed in an advertisement for the KMI in the Southern standard of 14 June 1851. It is interesting that in the Catalogue of Officers and Cadets of the KMI for 1856, both his AB degree and that of a fellow graduate, A.G. Gower, are noted as having been conferred ad eundum, that is, a courtesy degree awarded by one college to an alumnus of another, the recipient very often being a faculty member of the institution where he is receiving the honour. In Adcock's case, this may have been because he had begun his first degree course elsewhere and completed it at the KMI. He was conferred Master of Arts the following year.

He subsequently appears in the 1852-3 and 1854-5 Catalogues as: 'Major R.J. Adcock, A.M. Professor of Mathematics;' for 1856-7 as 'Professor of Mathematics and Mechanics;' and for 1857-8 as 'Professor of Mathematics, Mechanics and Astronomy.' He was evidently well liked by his pupils as an anonymous article in The Kentucky Military Institute Magazine 'edited by six cadets, elected by the Corps' for May 1857 says:

Major Adcock is a profound scholar as well as one of the ablest, most practical, and theoretical mathematicians of which our country can boast. He is fully competent to master the most abstruse and intricate theories, and conclusively proves to all those under him that he ... is well acquainted with the mysterious depths of Calculus and mechanics, and the other higher branches of Mathematics, as the urchin with the road to his country school house. ${ }^{33}$

During his time on the staff of the KMI, Adcock published two short notes ${ }^{34}$ and it is just possible that he discussed ideas regarding the properties of a revolving ellipsoid with his pupils, particularly as the 'figure of the world' was a topic which would have fallen under the subject

31 Campbell Edmonson James, A Short History of Franklin County, Kentucky. (G.A. Lewis, Frankfort, 1881); Tommy R. Young. II, Character Makes the Man. Kentucky Military Institute, 1845-1871.

(Trafford Publishing, Bloomington, IN, 2013); annual Catalogues of the WMI and KMI.

32 Albert E. Church, Elements of the Differential and Integral Calculus. (Wiley \& Putnam, New York, 1842).

33 Anonymous (ed.), The Kentucky Military Institute Magazine, 1, 90 (1857).

34 Robert J. Adcock, 'On an interesting mechanical problem'. The Astronomical Journal, 4, 94 (1855); 'Demonstration of Prof. Peirce's propositions on the distribution of points on a line'. The Mathematical Monthly, 1, 82-84 (1858). 
matter of 'Physical Astronomy'. ${ }^{35}$ A more satirical piece in the April 1857 issue of the KMI Magazine described A mathematical world, in which the writer imagined being approached by a being whose body is formed of a 'prolate spheroid:'

The front of the spheroid that formed the body opened like a door on hinges, and the inside was fitted up with shelves which were filled with pocket editions of every mathematical work from Arithmetic to the Méchanique Celeste. ... The spheroid began to whirl about its longer axis, the arms became horizontal, by virtue of the centrifugal force, the closet door flew open, and out bounced the formulae for "translation through space." 36

Copies of the KMI Calendar for 1858-9 no longer appear to exist, so the last glimpse we have of Adcock in these years is the photograph (Fig. 1) which appeared in a Class Yearbook for 1859, which was the property of graduating student Cassius E. Merrill (1861-1919), now held by the Kentucky Historical Society.

Beyond the borders of the Institute, immense changes were beginning to take place. Between August and October 1858, Democrat Steven A. Douglas and Republican Abraham Lincoln held seven debates in Illinois on the problem of slavery, its future and inevitability. Lincoln visited Macomb twice, on 25 August and 25 October 1858, and news of these debates would have reached Adcock in Frankfort. During his years in Frankfort he would have seen slaves, and it is significant that he was the only member of his family to become a Republican. ${ }^{37}$ A raid by armed slaves, led by John Brown, on the Federal Arsenal at Harper's Ferry, Virginia, in October 1859, led to intense discussion, with blame for the violence being attributed by many to the anti-slavery platform of the Republican Party. On 6 November 1860, Lincoln was elected President but without a single Southern vote. When South Carolina became the first of the Southern states to secede on 20 December, three days previously the cadets of the KMI had 'tendered their services to the citizens of South Carolina, and hold themselves in readiness for any emergency ... As we are sons of the noble South, we are anxious to come and help defend our Southern rights. ${ }^{38}$ With tensions growing, student enrolment began to drop, and after Civil War was declared on 12 April, 1861, there was a 'wholesale exodus of cadets,' the KMI ceased to function and its buildings were sold in $1863 .{ }^{39}$

\section{RETURN TO ILLINOIS}

Merrill made a pencilled annotation on the surround of his photograph of Adcock which reads 'Died insane.' On 21 December 1859, Adcock entered the Illinois State Hospital for the Insane (ISHI) at Jacksonville in Morgan County, IL. ${ }^{40}$ On the list of the ISHI inmates in the 1860

\footnotetext{
35 David Brewster (ed.), The Edinburgh Encyclopaedia. 18 vols (W. Blackwood and J. Waugh, Edinburgh, 1830); II, 705-711.

36 Anonymous, op. cit. (note 33); I (2), 50-51.

37 Anonymous, op. cit, (note 15), at. p. 318.

38 The Daily Dispatch, 1 December 1860. (https://dispatch.richmond.edu/view/secondary-section-view. php?doc= D_018_131\&q=Sons\%20of\%20the\%20Noble\%20South\&start=1\&num= $10 \& \operatorname{div}=\operatorname{article} \& \mathrm{dn}=8)$.

39 Young, op. cit. (note 32) at pp. 18-20.

$40 \quad$ Shirley Aleguas, Florence M. Hutchison and Warren W. Haley, Directory of Jacksonville State Hospital Patients 1854-1870. (2000a) (http://www.rootsweb.ancestry.com/ ilmaga/morgan2/ statehosp/mcsh_adm.html); Jacksonville State Hospital Patients Listed in the 1860 Morgan County IL Census. (2000b) (http://www.rootsweb.ancestry.com/ ilmaga/morgan2/mc-sh_1860.html).
} 
Federal Census, his occupation was given as 'teacher.' His next of kin and guardian was his brother, who would have been responsible for the expenses during his time in the hospital. It is possible that Adcock's mental breakdown might have been connected both with the death of his father (7 May 1859) and, as a future member of the Republican Party, increasing stress from the political situation. There is no information as to what the exact nature of his illness might have been and, unfortunately, records of this age for hospital admissions in Illinois are still closed. ${ }^{41}$ However, given his sex, age and length of admission, it is possible that he could have been diagnosed as having 'chronic dementia,' a condition which in modern terms may have been 'at least somewhat related to schizophrenia'. ${ }^{42}$ Following his release, on 14 August 1861, Adcock seems to have tried to resume a career as a teacher in a local school, but the stress may have proved too great. The Macomb Journal of 31 January 1862 reported:

School House Discussions - We learn that a few zealous Democrats in the School District a few miles east of town, of which Mr. Adcock is teacher, are inviting their Republican friends to a discussion of the following question: Resolved, That the Abolitionists is [sic.] the cause of the war. ${ }^{43}$

He was scheduled as a speaker at a meeting of the McDonough County Teacher's Association on 27 March. ${ }^{44}$ However, by the time he and his brother registered for the Civil War Draft, intended to provide more manpower for the Union Army, in July $1863,{ }^{45}$ he had begun what would become a very successful farming career. Neither brother seems to have served, but as Joseph Adcock was by then a wealthy man (with an income in 1865 of $\$ 2,325 \quad[\$ 36,100$ today]), ${ }^{46}$ they may well have used the option of paying $\$ 300$ to get out of the obligation ${ }^{47}$ and to continue their lives as farmers.

\section{Mental illness strikes again}

Adcock published nothing during the years of the Civil War and for a few years after it had ended. From 9 December 1868 to 16 May 1871, he was again confined to the ISHI but, as before, the diagnosis is unavailable. ${ }^{48} \mathrm{He}$ had been brought up in a community of church-going settlers and is mentioned in local papers as being a member of the Christian Church, ${ }^{49}$ another

41 The early history of the hospital and the kind of patients it held is discussed in: Richard J. Howarth and Shirley A. Aleguas 'Through a glass darkly: Patients of the Illinois State Hospital for the Insane at Jacksonville, U.S. (1854-1880)', History of Psychiatry, 30, 150-171 (2019).

42 Simon A. Hill and Richard Laugharne, 'Mania, dementia and melancholia in the 1870s: admissions to a Cornwall asylum'. Journal of the Royal Society of Medicine, 96, 361-363 (2003).

43 The Macomb Journal, vol. 7 (17), 31 January 1862, at p. 3. 'R. Adcock' is also listed among those who taught at the school house in Maple Grove, District no. 2, in McDonough County (Fig.3) in: Samuel J. Clarke (ed), History of McDonough County Illinois, its cities, towns and villages with early reminiscences, personal incidents and anecdotes, and a complete business directory of the county. (D.W. Lusk, Springfield, IL, 1878) at p. 423.

$44 \quad$ The Macomb Journal, vol. 7 (24), 21 March 1862, at p. 3.

45 Ancestry.com. U.S., Civil War Draft Registrations Records, 1863-1865 [database on-line]. (Provo, UT, USA: Ancestry.com Operations, Inc., 2010).

46 Ancestry.com. U.S. IRS Tax Assessment Lists, 1862-1918 [database on-line]. (Provo, UT, USA: Ancestry.com Operations Inc., 2008).

47 Melissa Traub, "\$300 or Your Life”: Recruitment and the Draft in the Civil War. Honors Scholar Theses. 468. [University of Connecticut] (http://digitalcommons.uconn.edu/srhonors_theses/468, 2015).

48 Aleguas et al., op.cit. (note 40).

49 The Evening Gazette (Monmouth; January 21, 1886, at p.4) and the Republican-Atlas (Monmouth; July 19, 1895, at p.4) (https://idnc.library.illinois.edu). 
name for The Disciples of Christ, a Protestant Christian denomination which established one of its earliest congregations in Warren County, IL, in 1832, at Coldbrook, 'on the Cedar Fork of the Henderson River,' close to where the Adcock family had originally settled. By 1845, a second church had also opened in Macomb. ${ }^{50}$ Occasional brief mentions of Adcock in local newspapers over the years confirm that he actively engaged in church affairs and, rather surprisingly, in 1872 he chose the Gospel Echo and Christian, a weekly religious paper published by the Disciples, in which to first advertise the publication of his pamphlet Gravitation to the sphere. ${ }^{51}$

Although one of his later papers concludes 'the bearing of fluidity upon the stability of the [solar] system and the great changes which are to take place, some probably in consequence thereof, are very clearly referred to in the book of Psalms, in the Prophets, by our Saviour himself in the Gospels of Matthew and Mark, by the Apostle Peter, and in the book of Revelation of the Apostle John', ${ }^{52}$ this may simply have been an expression of his religious belief at a time when Darwinism was presenting 'a fundamental challenge to the conventional wisdom about harmony between science and religion', ${ }^{53}$ rather than an indication of mental disturbance.

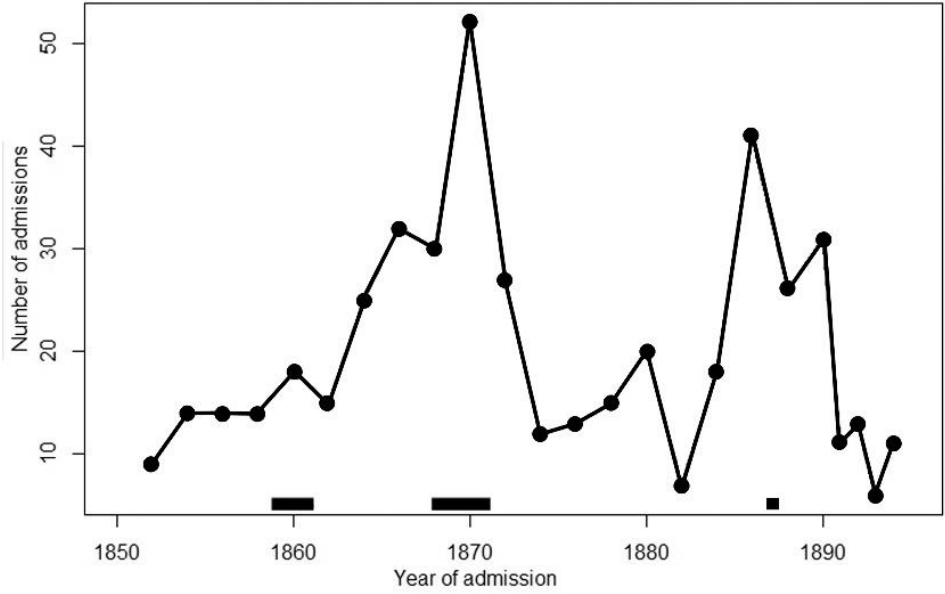

Fig. 4. Admissions to the Illinois State Hospital for the Insane (1856-1894) of persons diagnosed with 'religious insanity;' frequency data from hospital reports. ${ }^{55}$ Horizontal bars at the base show Adcock's known periods of admission.
The distinction between religious fervour and mental illness can still be difficult to make, ${ }^{54}$ but at the time Adcock was in the ISHI on this second occasion, 'religious excitement' was a well-known supposed cause of insanity in the United States (Fig. 4). ${ }^{55}$ Wilkins gives it as the principal cause in $9.9 \%$ of 5314 admissions in 26 asylums in $1869,{ }^{56}$ and Morison ${ }^{57}$ lists 'excessive mental exertion, including much reading on religious and abstruse subjects Religious doubts and fears, and

50 Nathaniel S. Haynes, History of the Disciples of Christ in Illinois 1819-1914. (The Standard Publishing Co., Cincinnati, 1915); Anonymous, op. cit. (note 16).

$51 \quad$ William E. Tucker, J.H. Garrison and Disciples of Christ. (Bethany Press, St. Louis, 1964), at p. 50.

52 Robert J. Adcock, 'On the Stability of the Solar System'. The Analyst, 1, 120-121 (1874b), at p. 121.

53 Paul Jerome Croce, 'Science and religion' in: Encyclopedia of American Cultural and Intellectual History, vol. 1. Antebellum, Civil War and Reconstruction: 1838-1877 (eds. Mary Kupiec Cayton and Peter W. Williams). (Charles Scribner's Sons, New York, 1999)

(https://www.stetson.edu/artsci/american-studies/pc19thscience.php).

$54 \quad$ Nathaniel P. Morris, 'MIND Guest Blog. How Do You Distinguish between Religious Fervor and Mental Illness?' Scientific American [weblog], 22 December 2016, https://blogs.scientificamerican.com/mind-guest-blog/how-do-you-distinguish-between-religious-fervorand-mental-illness/.

55 Julius H. Rubin, Religious melancholy and Protestant Experience in America. (Oxford University Press, New York, 1994); see also Loren A. Broc, Religion and Insanity in America from Colonial Times to 1900. PhD thesis. (University of Rochester, Rochester, New York, 2013). (http//:hdl.handle.net/1802/ 27925). Data for Fig. 4 is based on Broc's Table 9.

56 Edmund T. Wilkins, Insanity and Insane Asylums. (T.A. Springer, Sacramento, 1872); Appendix A.

$57 \quad$ Alexander Morison, The Physiognomy of Mental Diseases. (Longman, London, 1840) at p. 288. 
change of Religious opinions' as the cause of $5.5 \%$ of 418 admissions in England. ${ }^{58}$ Nevertheless, it may be purely coincidental that Adcock's second period of hospitalization coincided with a sharp rise in admissions to the ISHI on the grounds of 'religious insanity' ${ }^{59}$

It was shortly after this that the long series of brief contributions to mathematical journals under the name of 'R.J. Adcock' began to appear (Fig. 2) and it is just possible that his prowess at 'analysis' and his concentration on solving the problem of Gravitation to the sphere and the two ellipsoids of revolution: ratio of the axes of a rotating fluid mass might have helped him to survive his time as a mental hospital patient in an era when it was not unknown for persons who would today be considered sane to suffer confinement (see, for example, the testimony of Elizabeth Packard who was also a patient in the ISHI). ${ }^{60}$

\section{Establishing authorship}

During Adcock's lifetime, there were three other persons who were referred to as 'R.J. Adcock' or 'Robert J. Adcock' living in Illinois, and who need to be eliminated as potential authors of the mathematical papers:

(1) Robert James Adcock (1831-1895) was also born in Virginia, and was a distant relative via a half-brother. By 1856, he had married and moved to McDonough County, IL (Fig. 3), and by 1863 he was running a thriving grocery business in Macomb. However, in 1870, he moved with his family to Monterey Co., CA, where he became a grocer and bee-keeper, and he died there. ${ }^{61}$

(2) Robert J. Adcock (1834?-1865) was born in Tennessee, but lived most of his life in Massac County, IL (Fig. 3), where he was a farmer. In 1862 he enlisted as a Union soldier in the Civil War. He died in 1865 when the Steamer General Lyon, returning discharged Union soldiers at the end of the war, caught fire and sank off Cape Hatteras, NC. ${ }^{62}$

(3) Robert James Adcock (1856-1940) was one of the children of Robert Jackson Adcock's brother, Joseph. He was born in Kelly Township in Warren County and, like many others in the family, attended Knox College (1875-8) where he gained his AB. At the Commencement ceremony, he reportedly 'delivered a fine oration on "Independence in Politics". ${ }^{63}$ Although, according to the 1880 Federal Census and Knox College Catalogues of 1880 and 1883, he initially worked on his father's farm, by 1884 he had become a practicing attorney-at-law in Monmouth. ${ }^{64}$ As the Illinois College of Law and the Illinois bar exam were not established until 1897, he would probably have studied law in a lawyer's chambers and simply begun

58 See Morison, op. cit. (note 57) at pp. 115-117; Andrew McFarland, 'Superintendent's Report', in: Fifth Biennial Report of the Trustees, Superintendent, and Treasurer of the Illinois State Hospital for the Insane at Jacksonville. December, 1856. (F. Fulton, Chicago, 1857) at p. 201; and D. Hack Tuke, A Dictionary of Psychological Medicine giving the definition, etymology and synonyms of the terms used in medical psychology. 2 vols. (P. Blakiston \& Son, Philadelphia, 1892), vol. 2 at pp. 1091-92; for contemporary discussion.

59 Frustratingly, his hospital records, along with those of all other patients of the ISHI are still under seal; see Howarth \& Aleguas, op. cit. (note 42) for discussion.

60 Elizabeth Parsons Ware Packard. The Prisoner's Hidden Life, or, Insane Asylums Unveiled: as demonstrated by the Report of the Investigating Committee of the Legislature of Illinois, together with Mrs. Packard's Coadjutors' Testimony. (J.N. Clarke, Chicago, 1871). http://person.ancestry.co.uk/tree/53822040/person/13581366971/facts. Entries in the Macomb Journal and Macomb Eagle (1863-5); obituary in The Macomb Journal, 13 June 1895, at p.1 (https://idnc.library.illinois.edu).

62 Ancestry.com, U.S. Civil War Soldier Records and Profiles, 1861-1865 [database on-line] (Provo, UT; Ancestry.com Operations Inc., 2009); The New York Times, April 3, 1865 (https://nyti.ms/1LwgxB9).

63 Monmouth Review, 5 July 1878, at p.3 (https://idnc.library.illinois.edu).

64 The Evening Gazette, Monmouth, 30 Aug. 1884, at p.4; 13 Aug. 1885, at p.4; 16 Jan. 1885 (https://idnc.library. illinois.edu). 
to practice (M. McAndrew and J. Jenkins, pers. comms. 2018). By 1888, he was established as an attorney in Los Angeles, where he spent the rest of his life. Admitted to practice in the Supreme Court of California in 1891, he founded the successful law firm of Adcock \& Reymery. He was also very active in politics and frequently visited Monmouth for this purpose, but he eventually stood as the Democratic nominee for District Attorney in Los Angeles in 1902 and 1904. ${ }^{65}$

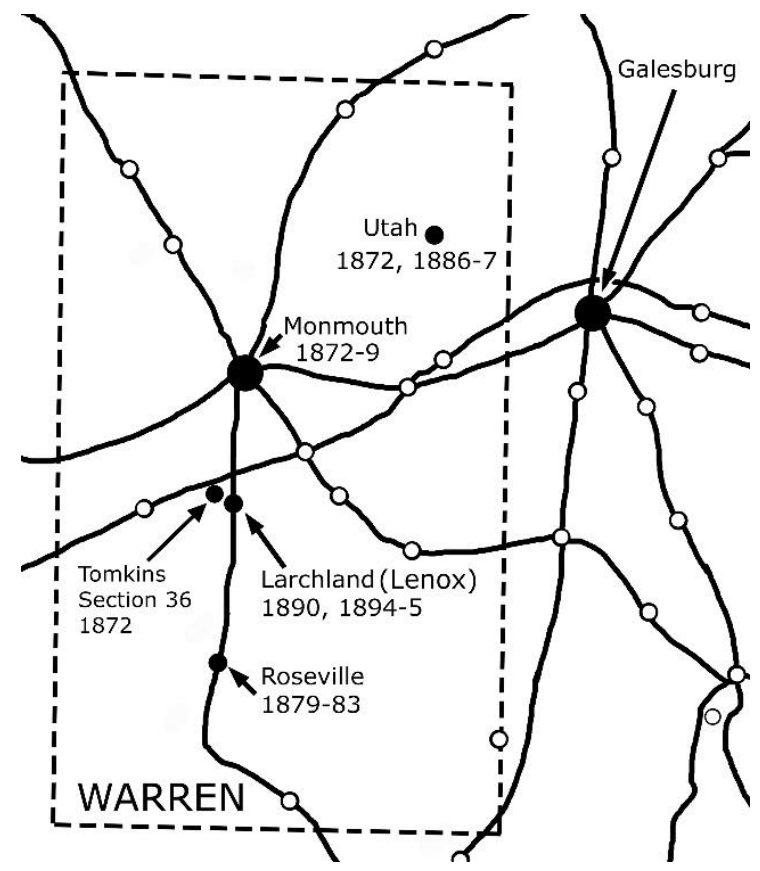

Fig. 5. Locations in Warren County from which Adcock's publications etc. were sent, and when. Solid lines are railroads, which were built after 1855. Redrawn from 'Warren County Illinois 1895' at http://www.livgenmi. com/1895/IL/County/warren.htm.

At this time, the place given as an author's address in a publication would have been their local post office and, as Fig. 5 shows, in the case of 'R.J. Adcock,' these all lie in Warren County, IL. Thus, on the basis of the evidence, these three people can all be removed from consideration as authors of the papers, on account of: their probable lack of appropriate education in persons 1 and 2 and, in all three cases, their domiciles at the time the papers were written. It may therefore be concluded that the author of the post-1871 papers is definitely the same person as the former Professor of Mathematics at the KMI.

Adcock had evidently been interested in the problem of the gravitational potential of a rotating ellipsoid since his days of teaching at the KMI and, as remarked above, it is possible that he may have started writing, or at least seriously thinking about his paper Gravitation to the sphere when he was in the ISHI. Released in May 1871, he was listed as a speaker at the $20^{\text {th }}$ meeting of the American Association for the Advancement of Science (AAAS) in Indianapolis, Indiana, on 21 August, but it seems that he did not actually attend. ${ }^{66}$ A copy of his privately published pamphlet was received by the Royal Society in London, England, in the week of 7 March, 1872 and a copy in the U.S. Library of Congress is dated 1872, although it appears in the Catalogue of books added ... during the year $1871 .{ }^{67}$ Curiously, a Catalogue of the Illinois State Library, Springfield, $\mathrm{IL}^{68}$ contains an entry: 'Gravitation of a Rotating Fluid Mass. R.J. Adcock. [Size] $8^{\circ}$; [Place] Washington; [Date] 1869.' Unfortunately, whatever it was that this entry referred to is no longer held by the library; if correct, it must relate to an earlier version of his pamphlet, perhaps printed in Washington to lodge with the Library of Congress, but there

65 Los Angeles Herald, 14 Aug 1904, at p.4 (https://cdnc.ucr.edu).

66 ' 65 . The force at any point of the Surface of a rotating fluid ellipsoid of three unequal axes, under the action of the gravity of its own particles and the accompanying centrifugal force. By R.J. Adcock.' Programme for Friday, Saturday and Monday, August 18, 19, and 21, 1871. American Association for the Advancement of Science. Palmer, Winall \& Co., Dubuque; at p. 8; Proceedings of the American Association for the Advancement of Science. Twentieth Meeting, held at Indianapolis, Indiana. August, 1871. Joseph Lovering, Cambridge. (1872).

67 Anonymous, 'Presents received March 7, 1872'. Proceedings of the Royal Society of London. 20, 264265 (1872a); Catalogue of Books added to the Library of Congress during The Year 1871. (Government Printing Office, Washington, 1872b). Anonymous, Catalogue of the Illinois State Library. 1880. (H.W. Roekee, Springfield, 1880) at p. 157. 
is no record in the Library of Congress Catalogues for 1868-72, apart from the one mentioned above. Another copy is recorded in the Catalogue of the library of the U.S. Military Academy at West Point, for 1873 and it also appears among a list of mathematical books published by Macmillan \& Co., in Cambridge, England, at a price of two shillings and six pence, equivalent to about $£ 11.18[\$ 14.54]$ today. ${ }^{69}$

An anonymous letter to The Analyst in March 1872 (quoted in Part I of this paper), criticised Gravitation to the sphere and it too implies that a different (?earlier) version of his pamphlet may have existed. Nevertheless, it seems that it was not until January 1872 that Adcock began to publicise its availability, ${ }^{50}$ before reading it at the AAAS meeting in August that year. ${ }^{70}$ Annual membership lists show that he retained his AAAS membership until 1877. ${ }^{71}$

Between 1874 and 1884, Adcock contributed regularly to The Analyst, but on its cessation he gave his copies of the journal to the Warren County Library. ${ }^{72}$

He was able to indulge in mathematics as a hobby because he was by that time a wealthy man. The U.S. Federal Census agricultural inventory for June 1880 lists him as owning 470 acres of land with a total value for the farm of $\$ 14,100$ [\$349,000 today], livestock valued at $\$ 3,200$ [ $\$ 79,200]$ and an estimated value of all his farm produce for the previous year as $\$ 1,740$ $[\$ 43,000]$. Nevertheless, he seems to have had ongoing mental health problems. On Tuesday 8 March 1887, it was reported:

Robert Adcock ... has been in jail since Saturday night. The immediate cause of his arrest was his killing a horse with a crowbar. Not only this act but many others on his part have convinced many that he is insane. [The following day] a telegram received from Jacksonville stated that there was no room in the Asylum ... The court ordered Mr Adcock be taken into the custody . . . pending admission. ${ }^{73}$

He was eventually transferred on 16 March, but cannot have been detained long, as by 3 April, 'Mrs. Hogan and daughter . . . visited at Robert Adcock's Sabbath afternoon'. ${ }^{74}$ There is no other information as to how long he was in the ISHI at this time (nor whether there were any other occasions on which he might have been admitted) as the official State of Illinois records are still closed. ${ }^{75}$ Adcock's next mathematical contributions appeared in The Annals of Mathematics in 1889 and early 1890.

69 Robert Henry Hall, Catalogue of the Library U.S. Military Academy, West Point, N.Y. 1873. (Charles Jannicky, Newburgh, N.Y, 1876); Anonymous. 'A catalogue of mathematical books on sale by Macmillan \& Co., Cambridge'. The London, Edinburgh, and Dublin Philosophical Magazine and Journal of Science. Fifth Series. 1, April 1876; advertisements at rear, at p.2. (1876). Adcock's paper (with the same number and title as in note 67) is listed in the Programme of the American Association for the Advancement of Science, Twenty-first Meeting, held at Dubuque, Iowa, August, 1872. Programme for Fifth day, Monday, August 26th; and in the Proceedings of the American Association for the Advancement of Science, Twenty-first meeting, held at Dubuque, Iowa. August, 1872. Joseph Lovering, Cambridge (1873), 'Adcock, Robert J., Lenox, Illinois' appears under 'Members who joined at the Dubuque Meeting'.

71 His address 1873-77 is given as 'Monmouth, Warren County, Illinois.'

72 The Evening Gazette, Monmouth, 7 April 1884, at p.3. (https://idnc.library.illinois.edu).

$73 \quad$ Ibid. (note 72), 8 March 1887, at p.4.

$74 \quad$ Ibid. (note 72), 6 April 1887, at p.1.

75 Unfortunately, the source which the Aleguas et al. (2000a) transcription (op. cit., note 41) was based on ends with admissions in 1870 . 
As a wealthy farmer living on his own, he was vulnerable. On 4 May 1890 he was attacked, robbed of $\$ 1340$ [ $\$ 38,200]$, and badly beaten, probably by an employee he had discharged the previous week. ${ }^{76}$ He was the victim of two further, more minor, robberies in 1892 and 1894 but, despite these incidents, when The American Mathematical Monthly began publication in 1894, he again began to contribute solutions to set problems. However, the following year, having been 'in poor health for some time,' he was found ill at his home and was moved to his brother's house, where he died of pneumonia on Sunday 14 July. Described in the funeral notices as 'a kind and affectionate brother, uncle and friend' and 'a good citizen and an upright man,' he is buried in Hope Cemetery, Warren Co., IL. ${ }^{77}$ There is no evidence that Merrill's annotation that Adcock 'died insane' is correct. His last contributions appeared posthumously in The American Mathematical Monthly in the autumn of 1895 and in March 1896. His estate was administered in August 1895 by his brother, assisted by two of his sons, ${ }^{78}$ one of whom, Edmund David Adcock (1854-1911), by then established as a successful patent lawyer in Chicago, had apparently inherited his uncle's aptitude for mathematics and was bequeathed many of his mathematics and astronomy books. ${ }^{79}$

\section{CONCLUSIONS}

Hitherto, the identity of 'R.J. Adcock' has been a matter of speculation. We have shown that, apart from his years spent first as a student (1850-51) at the Western Military Institute at Blue Lick Springs, KY, then as Professor of Mathematics, Mechanics and Astronomy in the same institution at Drennon Springs, KY (1851), and its successor, the Kentucky Military Institute at Frankfort, KY (1851-59), he resided in Illinois. Shortly before the outbreak of the Civil War, in 1859, he returned to Illinois and became a patient in the Illinois State Hospital for the Insane. On his release in 1861, he was a schoolteacher for a short while before taking up a farming career. This became so successful that he could afford to dabble in mathematics as a recreation and he appears to have had little interaction with the wider mathematical community. His pamphlet on the figure of the earth (1872), and his now well-known papers on regression, were all associated with addresses in Warren County, IL, and this eliminates the possibility that they were written by his nephew, Robert James Adcock (1856-1940), who became a successful lawyer in Los Angeles.

His work on the figure of the earth (discussed in Part I) gave the complete solution of a problem first considered, but not solved, by Newton, Laplace, Gauss and Dirichlet: namely, finding the gravitational field of a rotating self-gravitating homogeneous ellipsoidal fluid mass. He derived a formula which, until now, was thought to have been first obtained using potential

Monmouth Review, 6 May 1890, at p.4; Warren County Democrat, 8 May 1890, at p.5; 22 May 1890, at p.8. (https://idnc.library.illinois.edu).

77 Warren County Democrat, 18 July 1895, p.8; Republican-Atlas, 19 July 1895, at p.4. (https://idnc.library.illinois.edu). Hope Cemetery is today located at the intersection of $170^{\text {th }}$ St. E and $245^{\text {th }}$ Ave. N., approximately $5 \mathrm{mi}(8 \mathrm{~km}) \mathrm{NW}$ of Knox College in Galesburg. Illinois, Wills and Probate Records, 1772-1999 (Ancestry.co.uk).

79 J. Seymour Currey, Chicago: Its history and builders. A Century of marvellous growth, vol 5. (S.J. Clarke, Chicago, 1912), at pp. 238-40. 
theory in 1935, and he calculated a value for the inverse flattening very close to that obtained using modern analytic techniques. ${ }^{80}$ It was a remarkable achievement for its time, and one for which this farmer-mathematician deserves more recognition.

\section{ACKNOWLEDGEMENTS}

We would like to thank: Rupert Baker, Library Manager, The Royal Society, and his staff for their help with Adcock's Gravitation to the sphere and the Kentucky Historical Society for permission to use Robert Adcock's portrait; and to Katherine M. Costin, University of Nashville; Julianna Jenkins, University of California at Los Angeles, Special Collections; Michelle Harm, Special Collections Manager, Venice Museum and Archives [Florida]; and Maryjo McAndrew, Senior Archive Assistant, Knox College for information; to Stephen Stigler for providing a copy of his 2016 lecture; and to Walter Stromquist and R. William Farebrother for their interest and encouragement.

80 Wolfgang H. Müller, 'The effect of rotation on the flattening of celestial bodies: A journey through four centuries'. Mathematics and Mechanics of Complex Systems. 6, 1-40 (2018).

(https://msp.org/memocs/2018/6-1/memocs-v6-n1-p01-p.pdf; dx.doi.org/10.2140/ memocs.2018.6.1.). 